\title{
PEMBINAAN KESISWAAN UNTUK PENUMBUHAN DAN PENGUATAN KARAKTER KEPEMIMPINAN MELALUI KEGIATAN OSIS
}

\author{
Siti Hajar, Agus Tinus, Budiono \\ FKIP Universitas Muhammadiyah Malang, Indonesia \\ Email: sitihajarirfai@gmail.com
}

\begin{abstract}
ABSTRAK
Penelitian ini bertujuan untuk mengetahui (1) desain kegiatan untuk menumbuhkan dan menguatkan karakter kepemimpinan; (2) pelaksanaan kegiatan OSIS yang merupakan salah satu kegiatan pembinaan kesiswaan di SMK Negeri 2 Blitar; (3) dampak terhadap penumbuhan dan penguatan karakter kepemimpinan karena program kegiatan OSIS untuk menumbuhkan dan menguatkan karakter kepemimpinan tidak tersusun secara terstruktur dan kurang nampak yang disebabkan kegiatan di SMK lebih banyak praktik sesuai dengan program keahlian masing-masing dan waktu untuk kegiatan organisasi tidak maksimal. Metode penelitian menggunakan deskriptif kualitatif yang dilakukan di SMK Negeri 2 Blitar. Hasil penelitian menunjukkan: (1) Desain yang diterapkan untuk menumbuhkan karakter kepemimpinan adalah personal development, desain untuk menguatkan karakter kepemimpinan adalah melalui pelaksanaan kegiatan yang masuk dalam rencana kerja OSIS. (2) Pelaksanaan kegiatan secara keseluruhan telah dilakukan dengan baik sesuai dengan desain yang telah dibuat. (3) Dampak terhadap penumbuhan dan penguatan karakter kepemimpinan bersifat positif tercermin dengan munculnya karakter integritas yang merupakan ciri seorang pemimpin ideal.
\end{abstract}

Kata kunci: Pembinaan Kesiswaan; Kepemimpinan; OSIS

\begin{abstract}
This study aims (1) to determine the design of activities to grow and strengthen the character of leadership; (2) the implementation of student council which is one of the student development activities at State Vocational High School 2 Blitar; (3) the impact on growth and strengthening the character of leadership because the student council program activities to grow and strengthen leadership character are not structured and less visible caused activities in Vocational Schools are more practice in accordance with their respective expertise and time for organizational activities are not optimal. The research method used qualitative descriptive conducted at SMK Negeri 2 Blitar The results of the study show: (1) the design applied to grow leadership character is personal development, design to strengthen the character of leadership is through the implementation of activities included in the student council work plan. (2) The implementation of the overall activities has been carried out well according to the design that has been made. (3) The impact on growth and strengthening the character of leadership is positively reflected by the appearance of the character of integrity which is characteristic of an ideal leader.
\end{abstract}

Keywords: Student Development; Leadership; Student Council

\section{PENDAHULUAN}

Pendidikan merupakan kebutuhan di Era Globalisasi saat ini. Pendidikan memiliki peran penting dalam kehidupan masyarakat. Pendidikan dibutuhkan apabila telah menyangkut kehidupan masyarakat baik dalam bidang akademis maupun non akademis sehingga setiap orang berharap memiliki pendidikan yang sukses agar dapat berkontribusi pada Era Globalisasi sekarang ini. Melalui pendidikan yang sukses, Indonesia akan mampu menghasilkan generasi muda yang siap dihadapkan pada segala macam 
situasi dan kondisi, siap menjadi pioneer dan mengubah sejarah kehidupan manusia, siap menjadi pemimpin peradaban dunia (Asmani, 2009:7).

Proses pendidikan di sekolah terdapat tiga bentuk yaitu kegiatan intrakurikuler, kokurikuler dan kegiatan ekstrakurikuler. Kegiatan intrakurikuler di Sekolah Menengah Umum berdasarkan pada Peraturan PerundangUndangan Nomor 20 Tahun 2003 Tentang Sistem Pendidikan dan Peraturan Pemerintah Republik Indonesia Nomor 19 Tahun 2005 Tentang Standar Nasional Pendidikan, menurut Kunandar (2007:191) yang dimaksud "kegiatan intrakurikuler adalah kegiatan pengembangan diri yang dilaksanakan sebagian besar di dalam kelas (intrakurikuler)". Kegiatan kokurikuler merupakan penunjang untuk kegiatan intrakurikuler seperti pekerjaan rumah atau tugas.

Kegiatan ekstrakurikuler menurut Wahjosumidjo (2010:197) adalah "kegiatan yang diselenggarakan di luar jam pelajaran yang tercantum dalam susunan program sesuai dengan keadaan dan dibutuhkan sekolah". Pengertian ekstrakurikuler menurut Kamus Besar Bahasa Indonesia adalah "suatu kegiatan yang berada di luar program yang tertulis di dalam kurikulum seperti latihan kepemimpinan dan pembiasaan siswa". Ekstrakurikuler merupakan kegiatan bukan pelajaranyang dilakukan di luar jam pelajaran. Ekstrakurikuler berperan sebagai pelengkap sekaligus pendukung kegiatan belajar di sekolah. Kegiatan pembinaan kesiswaan terdapat dalam kegiatan ekstrakurikuler yang diamanatkan dalam Peraturan Menteri Pendidikan Nasional Nomor 39 Tahun 2008. Pembinaan kesiswaan merupakan kegiatan yang memperkuat penguasaan kompetensi dan pengalaman belajar dengan membentuk karakter sesuai dengan tujuan pembentukan pembinaan kesiswaan.

Tujuan pembinaan kesiswaan sesuai amanat Peraturan Menteri Pendidikan Nasional Nomor 39 Tahun 2008 antara lain:
1. Mengembangkan potensi siswa secara optimal dan terpadu yang meliputi bakat, minat dan kreatifitas.

2. Memantapkan kepribadian siswa untuk mewujudkan ketahanan sekolah sebagai lingkungan pendidikan sehingga terhindar dari usaha dan pengaruh negatif dan bertentangan dengan tujuan pendidikan.

3. Mengaktualisasikan potensi siswa dalam pencapaian prestasi unggulan sesuai bakat dan minat.

4. Menyiapkan siswa agar menjadi warga masyarakat yang berakhlak mulia, demokratis, menghormati hak-hak asasi manusia dalam rangka mewujudkan masyarakat madani (civil society).

Kegiatatan pembinaan kesiswaan adalah bagian dari tahap implementasi pendidikan karakter di sekolah. Implementasi pendidikan karakter di sekolah melalui kegiatan pembinaan kesiswaan dapat dilakukan dengan berbagai kegiatan antara lain, pembinaan iman dan taqwa kepada Tuhan Yang Maha Esa, kegiatan masa orientasi peserta didik baru, kegiatan penegakan tata tertib sekolah, kegiatan ekstrakurikuler. pembinaan bakat minat dan lain-lain. Bentuk kegiatan dalam pembinaan kesiswaan dilakukan untuk menanamkan nilai-nilai karakter, salah satunya adalah karakter kepemimpinan.

Karakter kepemimpinan merupakan faktor yang sangat menentukan baik atau buruknya suatu organisasi. Keberhasilan organisasi tidak terlepas dari sosok pemimpin yang ada didalamnya, sehingga karakter kepemimpinan sangat diperlukan untuk mengaktualisasi kehidupan berbangsa dan bernegara yang baik dan relevan dengan tujuan pembinaan kesiswaan yang dilaksanakan dalam berbagai kegiatan ekstrakurikuler di sekolah.

Karakter kepemimpinan dapat ditumbuhkan dan dikuatkan melalui gerakan Penguatan Pendidikan Karakter atau PPK yang didalamnya memuat 5 
nilai utama yaitu Religius, Nasionalis, Mandiri, Gotong royong dan Integritas (RENAMAGI). Integritas merupakan landasan atau dasar pembentuk karakter kepemimpinan. Integritas penting bagi seorang pemimpin untuk mendapatkan kepercayaan dari pengikutnya. Kegiatan pembinaan kesiswaan sebagai usaha untuk menumbuhkan dan menguatkan karakter kepemimpinan dapat dilakukan pada berbagai kegiatan ekstrakurikuler seperti Pramuka, PMR, OSIS, maupun Paskibraka. Lebih spesifik peneliti ingin meneliti kegiatan pembinaan kesiswaan pada kegiatan OSIS karena merupakan satu-satunya organisasi yang ada di sekolah dan selalu ada di setiap sekolah. Berbeda dengan ekstrakurikuler lain yang tidak selalu ada di semua sekolah. OSIS sebagai salah satu wadah kegiatan pembinaan kesiswaan juga secara rutin melakukan kegiatan latihan kepemimpinan siswa. Kegiatan tersebut adalah Latihan Dasar Kepemimpinan Siswa atau LDKS. LDKS merupakan tahap yang harus dilakukan sebelum menjadi anggota OSIS sebagai upaya untuk menumbuhkan jiwa kepemimpinan dan keterampilan serta pemahaman tentang organisasi.

Berdasarkan observasi awal yang telah dilakukan di SMK Negeri 2 Blitar, dimana program kegiatan OSIS untuk menumbuhkan dan menguatkan karakter kepemimpinan tidak tersusun secara terstruktur dan kurang nampak, hal tersebut disebabkan kegiatan di SMK lebih banyak praktik sesuai dengan program keahlian masing-masing sehingga waktu untuk kegiatan organisasi menjadi kurang maksimal, untuk itu penelitian ini ditujukan untuk mengidentifikasi lebih lanjut pelaksanaan kegiatan pembinaan kesiswaan yang berkaitan dengan penumbuhan dan penguatan karakter kepemimpinan pada organisasi OSIS. selain itu juga untuk mengetahui apakah pelaksanaan kegiatan tersebut telah berjalan dengan baik dan dapat menumbuhkan dan menguatkan karakter kepemimpinan sesuai dengan tujuan pembentukan pembinaan kesiswaan melalui OSIS. Penumbuhan dan penguatan karakter kepemimpinan dapat dilakukan dengan melaksanakan berbagai program kegiatan mulai dari tahap perencanaan hingga evaluasi kegiatan.

Menurut Kamus Besar Bahasa Indonesia, istilah pembinaan berasal dari kata "bina" yang berasal dari bahasa Arab "bana" yang berarti membina, membangun, mendirikan dan mendapat awalan pe dan akhiran an sehingga menjadi kata pembinaan yang berarti usaha, tindakan dan kegiatan. Menurut Wahjosumidjo (2010:241) pembinaan berarti usaha atau kegiatan memberikan bimbingan, arahan, pemantapan, peningkatan, arahan terhadap pola pikir, sikap mental, perilaku serta minat, bakat dan keterampilan.

Berdasarkan Peraturan Menteri Pendidikan Nasional Republik Indonesia Nomor 39 Tahun 2008, pembinaan kesiswaan merupakan kegiatan untuk mengembangkan potensi siswa sesuai dengan fungsi dan tujuan pendidikan nasional, yaitu siswa yang beriman dan bertakwa kepada Tuhan Yang Maha Esa, berakhlak mulia, sehat, berilmu, cakap, kreatif, mandiri, dan menjadi warganegara yang demokratis serta bertanggungjawab, diperlukan pembinaan kesiswaan secara sistematis dan berkelanjutan.

Tujuan pembinaan kesiswaan tersebut antara lain: (1) Mengembangkan potensi siswa secara optimal dan terpadu yang meliputi minat, bakat dan kreativitas; (2) Memantapkan kepribadian siswa untuk mewujudkan ketahanan sekolah sebagai lingkungan pendidikan sehingga terhindar dari usaha dan pengaruh negatif dan bertentangan dengan tujuan pendidikan; (3) Mengaktualisasikan potensi siswa dalam pencapaian prestasi sesuai bakat dan minat; (4) Menyiapkan siswa agar menjadi warga masyarakat yang berakhlak 
mulia, demokratis, menghormati hak-hak asasi manusia dalam rangka mewujudkan masyarakat madani (civil society).

Wahjosumidjo(2010:241) menafsirkan pembinaan kesiswaan sebagai bagian integral daripada kebijaksanaan pendidikan dasar dan menengah, berjalan sesuai dengan program kurikuler. Dengan demikian tujuan pendidikan nasional yang ingin menciptakan manusia Indonesia yang cerdas dan berakar pada budaya bangsa, disampng dilaksanakan melalui program kurikuler perlu didukung dengan program-program ekstrakurikuler sebagai bagian yang tak terpisahkan dalam program pengajaran.

Tujuan yang hendak dicapai dari pembinaan kesiswaan OSIS menurut Wahjosumidjo (2010:242) antara lain: (1) Mengusahakan agar siswa tumbuh dan berkembang sesuai dengan tujuan pendidikan nasional; (2) Meningkatkan peran serta dan inisiatif siswa untuk menjaga dan membina sekolah sebagai wiyatamandala, sehingga terhindar dari usaha dan pengaruh yang bertentangan dengan budaya sekolah; (3) Menumbuhkan daya tangkal pada diri siswa dari pengaruh negatif yang datang dari luar maupun dari dalam sekolah; (4) Memantapkan kegiatan ekstrakulikulerdalammenunjangpencapaian kurikulum; (5) Meningkatkan apresiasi dan penghayatan seni; (6) Menumbuhkan sikap berbangsa dan bernegara; (7) Meneruskan dan mengembangkan jiwa semangat serta nilai-nilai 45; (7) Meningkatkan kesegaran jasmani dan rohani.

Penumbuhan menurut Kamus Besar Bahasa Indonesia adalah proses, cara, perbuatan menumbuhkan: esensi deregulasi bertujan mengupayakan. Penumbuhan berarti menumbuhkembangkan bibit yang sudah tertanam. Penumbuhan menurut Megawangi (2009:27) adalah upaya atau tindakan yang dilakukan oleh seseorang seperti layaknya menyemai benih, yaitu usaha yang dilakukan secara optimal, baik dan menyeluruh kepada anak didik dengan menekankan pada aspek knowing, feeling dan acting yang hasilnya akan terlihat pada waktu yang akan datang.

Winataputra (2005:18) menjelaskan pengertian penguatan sebagai suatu respon yang diberikan kepada siswa terhadap perilaku atau perbuatannya yang dianggap baik, yang dapat membuat terulangnya atau meningkatnya perbuatan atau perilaku yang dianggap baik. Pendapat lain dikemukakan oleh Nurhasnawati (2005:17) bahwa penguatan (reinforcement) adalah respon positif terhadap tingkah laku siswa yang dilakukan guru agar siswa terangsang aktif dalam belajar. Asril (2010:77) mengatakan penguatan adalah respon terhadap tingkah laku positif yang dapat meningkatkan kemungkinan berulangnya kembali tingkah laku tersebut. Penguatan tidak boleh dianggap sepele dan sembarangan, tetapi harus mendapat perhatian serius.

Prayitno (2009:52) mengatakan penguatan merupakan upaya pendidik untuk menguatkan, memantapkan atau meneguhkan hal-hal tertentu yang ada pada diri peserta didik. Apa yang dikuatkan tidak lain adalah hal-hal positif yang ada pada diri peserta didik, terutama tingkah laku positif yang merupakan hasil perubahan berkat upaya pengembangan diri peserta didik. Penguatan (reinforcement) dilakukan pendidik melalui pemberian penghargaan (reward) secara tepat yang didasarkan pada prinsip-prinsip pengubahan tingkah laku. Dengan penguatan yang dilakukan pendidik, peserta didik akan semakin kaya dengan tingkah laku positif yang secara kumulatif dan sinergis menunjang keaktifan siswa serta pencapaian tujuan pendidikan. Menurut Usman (2013:81) penguatan memiliki pengaruh berupa sikap positif terhadap proses belajar dan bertujuan sebagai berikut: (1) Meningkatkan perhatian siswa terhadap pelajaran; (2) Merangsang dan mingkatkan motivasi belajar; (3) Meningkatkan kegiatan belajar dan membina tingkah laku siswa yang produktif. 
Penguatan (reinforcement) adalah respon terhadap suatu perilaku yang dapat meningkatkan kemungkinan terulanginya kembali perilaku tersebut. Penguatan dapat dilakukan secara verbal dan nonverbal, dengan prinsip kehangatan, keantusiasan, kebermaknaan dan menghindari respon yang negatif (Mulyasa, 2011:77). Berdasarkan pemaparan ahli tersebut, dapat disimpulkan bahwa penguatan adalah suatu perlakuan untuk meningkatkan kemampuan dalam perilaku positif yang telah tertanam dalam diri pribadi yang dapat dilakukan dalam skala individu maupun kelompok agar tercapai tujuan yang diharapkan.

Griek dalam Zubaedi (2012:9) menyatakan bahwa karakter dapat di definisikan sebagai panduan daripada segala tabiat manusia yang bersifat tetap, sehingga menjadi tanda yang khusus untuk membedakan orang yang satu dengan yang lain. Karakter menurut kamus ilmiah popular Internasional (Budiono, 2005:288) adalah watak, tabiat, pembawaan. Menurut Kerschensteinr dalam (Kartono, 2005:84), elemen-elemen dasar dari karakter antara lain: (1) daya kemauan, yaitu: daya aktivitas yang ulet awet; (2) akal yang jelas, ceria atau terang: daya berfikir yang logis; (3) perasaan halus: kemudahan dan banyaknya keterharuan jiwa mencakup baik rasa halus yang bersifat indrawi maupun bersifat jiwani; (4) aufwuhlbarkeit: kedalaman dan lamanya keharuan jiwa.

Pikiran merupakan unsur terpenting dalam membentuk karakter. Pikiran menjadi semacam remote control untuk menentukan setiap perilaku seseorang. Apabila memiliki pola pikir positif maka akan terbentuk karakter positif, sebaliknya jika memiliki pola pikir negatif maka akan terbentuk karakter negatif pula. Pikiran memegang peran penting dalam membentuk karakter seseorang.

Kepemimpinan menurut Locke dalam Pidekso (2001:2) adalah sebagai suatu proses membujuk (inducing) orangorang lain menuju sasaran bersama. Definisi kepemimpinan terebut mencakup tiga elemen antara lain: (1) Kepemimpinan merupakan suatu konsep relasi (relational concept). Kepemimpinan hanya ada dalam proses relasi dengan orang lain (para pengikut). Apabila tidak ada pengikut, maka tidak ada pemimpin. Tersirat dalam definisi ini adalah premis bahwa para pemimpin yang efektif harus mengetahui bagaimana membangkitkan inspirasi dan berelasi dengan para pengikut mereka; (2) Kepemimpinan merupakan suatu proses. Agar bisa memimpin, pemimpin harus melakukan sesuatu. Seperti telah diobservasi oleh John Gardner (19861988) kepemimpinan lebih dari sekedar menduduki suatu otoritas. Kendati posisi otoritas yang diformalkan mungkin sangat mendorong proses kepemimpinan, namun sekedar menduduki posisi itu tidak menandai seseorang untuk menjadi pemimpin; (3) Kepemimpinan harus membujuk orang-orang lain untuk mengambil tindakan. Pemimpin membujuk pengikutnya melalui berbagai cara, seperti menggunakan otoritas yang terlegitimasi, menciptakan model (menjadi teladan), penetapan sasaran, member imbalan dan hukum, restrukturisasi organisasi, dan mengkonmunikasikan visi. Menurut Thoha (2010:9) kepemimpinan adalah kegiatan untuk memengaruhi perilaku orang lain, atau seni memengaruhi perilaku manusia baik perorangan maupun kelompok. Menurut Walgito (2003:102) kepemimpinan merupakan suatu deskripsi tentang kegiatan seseorang yang dinilai sebagai pemimpin, dan terdapat aspekaspek: (1) posisi sebagai pusat; (2) peranannya sebagai pemberi arah; (3) sebagai penggerak atau stimulator dari aktivitas atau kegiatan. Pengertian kepemimpinan lebih dititik beratkan pada segi fungsi dari pada segi struktur, oleh sebab itu kepemimpinan dapat dimaknai: (1) kepemimpinan merupakan ciri-ciri 
aktivitas seseorang yang dapat memengaruhi pengikutnya; dan (2) kepemimpinan merupakan suatu instrument untuk dapat melancarkan suatu kegiatan dalam rangka pencapaian tujuan.

Karakter kepemimpinan menurut Kadir (2001:5) merupakan hasil karya pendidikan, pelatihan, talent scouting dan pembiasaan, yang dipadukan dengan sinergi pembelajaran sepanjang hayat, diperkuat oleh daya nalar dan kecerdasan akal budi serta kecerdasan spiritual, seraya menyelaraskan dengan irama kehidupan yang sedang berkembang dan berubah cepat tak menentu. Dari pendapat ahli diatas dapat disimpulkan bahwa karakter kepemimpinan adalah suatu sifat dalam diri manusia yang dapat memengaruhi perilaku orang lain baik perorangan maupun kelompok.

Menurut Thoha (2010:9) kepemimpinan adalah kegiatan untuk memengaruhi perilaku orang lain, atau seni memengaruhi perilaku manusia baik perorangan maupun kelompok. Karakter kepemimpinan dapat ditumbuhkan dan dikuatkan melalui gerakan Penguatan Pendidikan Karakter atau PPK sesuai dengan amanat Peraturan Menteri Pendidikan dan Kebudayaan Nomor 20 Tahun 2018 Tentang Penguatan Pendidikan Karakter yang didalamnya memuat 5 nilai utama yaitu Religius, Nasionalis, Mandiri, Gotong royong dan Integritas, dengan karakter integritaas sebagai payung utama karakter kepemimpinan.

\section{METODE}

Penelitian ini menggunakan pendekatan penelitian kualitatif dengan jenis penelitian deskriptif. Menurut Sugiyono (2017:15) metode penelitian kualitatif adalah metode yang berlandaskan pada filsafat postpositivisme, digunakan untuk meneliti pada kondisi objek yang alamiah, (sebagai lawannya adalah eksperimen) dimana peneliti adalah sebagai instrumen kunci, teknik pengumpulan data dilakukan secara triangulasi (gabungan), analisis data persifat induktif/kualitatif, dan hasil penelitian kualitatif lebih menekankan makna dari pada generalisasi. Jenis penelitian deskriptif menurut Zuriah (2009:47) adalah penelitian yang diarahkan untuk memberikan gejala-gejala, faktafakta, atau kejadian-kejadian secara sistematis dan akurat, mengenai sifat-sifat populasi atau daerah tertentu.

Penelitian ini bertempat di SMK Negeri 2 Blitar. Proses penyelesaian memerlukan waktu 2-3 bulan dimulai pada bulan Desember 2018 sampai Maret 2019. Informan dalam penelitian antara lain: (1) Wakil Kepala Bidang Kesiswaan; (2) Pembina OSIS SMK Negeri 2 Blitar; (3) Pengurus OSIS SMK Negeri 2 Blitar.

Teknik pengumpulan data menggunakan: (1) Observasi, menurut Marshall dalam (Sugiyono, 2017.310) menyatakan bahwa melalui observasi, peneliti belajar tentang perilaku, dan makna dari perilaku tersebut. (2) Wawancara, menurut Esterberg dalam (Sugiyono, 2017.317) mendefinisikan wawancara adalah pertemuan dua orang untuk bertukar informasi dan ide melalui tanya jawab, sehingga dapat dikonstruksikan makna dalam suatu topik tertentu. (3) Dokumentasi, menurut Zuriah (2009:191), cara pengumpulan data melalui peninggalan tertulis, seperti arsip termasuk juga buku teori, pendapat, dalil atau hukum, dan lainlain yang berhubungan dengan masalahmasalah dalam penelitian.

Teknik analisis data terdiri dari tahapan pengumpulan data, reduksi data, penyajian data, penarikan kesimpulan. Upaya pengujian kredibilitas data dalam penelitian ini menggunakan prosedur Triangulasi Teknik, menurut Sugiyono (2017.373) dilakukan dengan mengecek data kepada sumber yang sama dengan teknik yang berbeda. misalnya data diperoleh melalui wawancara, lalu dicek 
dengan observasi, dokumentasi, atau kuesioner.

\section{HASIL DAN PEMBAHASAN \\ Desain Pembinaan Kesiswaan untuk Menumbuhkan dan Menguatkan Karakter Kepemimpinan Melalui Kegiatan OSIS di SMK Negeri 2 Blitar}

Berdasarkan hasil penelitian dan data dapat dikatakan bahwa pembinaan kesiswaan yang merupakan pelengkap sekaligus pendukung kegiatan belajar di sekolah dimulai dari sosialisasi OSIS kepada siswa baru sudah dilaksanakan. Pelaksanaan sosialisasi dilakukan pada saat akhir masa bakti kepengurusan OSIS. Sekolah mewajibkan setiap kelas untuk memberikan nama-nama kandidat pengurus OSIS, namun ternyata tidak semua menyerahkan. Hal tersebut disebabkan kurangnya minat dan kesadaran akan pentingnya berorganisasi. Kurangnya kesadaran tersebut dikarenakan banyak faktor antara lain: (1) Siswa SMK digiring dengan mind set setelah lulus menjadi pekerja kasar; (2) Tidak ada arahan dari orang tua yang dapat mendorong untuk aktif dalam organisasi; (3) Siswa SMK waktunya habis untuk praktik dari pagi hingga sore hari sehingga tidak ada waktu untuk kegiatan lain.

Rancangan kegiatan mengacu pada proposal kegiatan yang telah dibuat pada periode lalu dan pembina OSIS bertugas mengarahkan agar pengurus OSIS meninjau kegiatan apa saja yang telah dilakukan sebelumnya. Kegiatan OSIS secara terstruktur untuk menumbuhkan dan menguatkankarakterkepemimpinanterdapat dalam kegiatan LDKMS atau Latihan Dasar Kepemimpinan dan Manajemen Siswa sesuai yang dinyatakan. Materi yang ditekankan dalam kegiatan tersebut adalah tentang kepemimpinan, keagamaan dan tata krama, administrasi keuangan, suratmenyurat, dan kepemimpinan.

Pemberian materi dilakukan oleh guru SMK Negeri 2 Blitar dan juga pihak luar yang telah ditunjuk. Selain pemberian materi yang telah tersebut sebelumnya, kegiatan yang terdapat dalam LDKMS antara lain adalah pelatihan PBB dan fisik, kegiatan yel-yel, kegiatan pensi dan keakraban, kegiatan outbond, dan kegiatan baksos. Kegiatan untuk menumbuhkan dan menguatkan karakter kepemimpinan tidak cukup hanya melalui kegiatan yang ada di sekolah saja, melainkan yang paling penting adalah peran orang tua di rumah untuk mendidik agar anak memiliki sikap tanggung jawab yang merupakan ciri seorang pemimpin.

Desain kegiatan untuk menumbuhkan karakter kepemimpinan diwujudkan dalam bentuk personal development atau pengembangan diri, dimulai dengan mengenali diri sendiri sehingga mampu mengarahkan sekaligus mengembangkan karakter diri utamanya dalam memimpin. Personal development mengharuskan siswa untuk bertanggung jawab terhadap diri sendiri terlebih dahulu sehingga memiliki integritas sesuai dengan amanat Peraturan Menteri Pendidikan dan Kebudayaan Nomor 20 Tahun 2018 Tentang Penguatan Pendidikan Karakter, dengan begitu tanggung jawab yang lain juga ikut terlaksana dengan baik. Bertanggung jawab terhadap diri sendiri akan mendorong penumbuhan karakter secara alami pada siswa. Mereka akan sadar tentang pentingnya sikap kepemimpinan yang menjadi tugas besar serta tujuan adanya OSIS. Selain itu personal development juga menjadi tolak ukur dalam usaha siswa untuk mengenali kemampuan diri dengan usaha mandiri yang dilakukan. Esensi pengembangan diri bukan terletak pada usaha orang lain melainkan usaha diri sendiri.

Personal development bukan berarti berjalan sendiri namun juga diperlukan dukungan serta arahan dari orang lain seperti orang tua maupun pembina. Setiap saat pembina memberikan 
motivasi, mengarahkan dengan tujuan untuk mencapai kesuksesan baik dalam kegiatan OSIS maupun di luar kegiatan OSIS. hal tersebut sesuai dengan pendapat Megawangi (2009:27) yang mengatakan bahwa penumbuhan merupakan upaya dari pendidik, pembina atau guru untuk mengupayakan agar peserta didik dalam hal ini pengurus OSIS untuk mampu mengembangkan bibit yang sudah tertanan pada dirinya, karena pada dasarnya setiap diri manusia telah memiliki karakter kepemimpinan yang mendasar terhadap diri sendiri.

Desain kegiatan untuk menguatkan karakter kepemimpinan yang telah tertanam dalam diri adalah melalui pelaksanaan kegiatan atau melalui kepanitiaan dimana dalam kepanitiaan tersebut mengajarkan untuk saling mengerti satu sama lain, melaksanakan tugas dan kewajiban serta tanggung jawab yang telah diberikan. Sikap tanggung jawab tersebut merupakan sebuah komitmen untuk menjadi pribadi yang dapat dipercaya dalam perkataan, tindakan dan pekerjaan. Selain kegiatan yang dilakukan pengurus OSIS tersebut, hal utama dalam penguatan karakter kepemimpinan adalah dengan pemberian reward oleh pembina atau guru. Penghargaan tersebut tidak hanya berupa benda namun juga berupa pujian. Memberikan reward berdampak pada psikologis anak sehingga akan menimbulkan feedback berupa terulanginya lagi kegiatan-kegiatan dan capaian positif, seperti pendapat Asril (2010:77) yang mengatakan bahwa penguatan adalah respon terhadap tingkah laku positif yang dapat meningkatkan kemungkinan terulanginya kembali tingkah laku tersebut.

Pelaksanaan Pembinaan Kesiswaan untuk Penumbuhan dan Penguatan Karakter Kepemimpinan Melalui Kegiatan OSIS di SMK Negeri 2 Blitar.

Pelaksanaan kegiatan OSIS untuk menumbuhkan dan menguatkan karakter kepemimpinan di SMK Negeri 2 Blitar sesuai dengan hasil penelitian dapat dikatakan bahwa, kegiatan OSIS merupakan agenda untuk membantu kegiatan sekolah seperti dies natalis atau orientasi siswa baru sehingga yang dipelajari adalah tentang kepanitiaan. Meskipun begitu, dalam kepanitiaan juga diperlukan sikap kepemimpinan, dimana dalam kepanitiaan tersebut mengajarkan untuk saling mengerti satu sama lain, melaksanakan tugas dan kewajiban serta tanggung jawab yang telah diberikan, sikap tanggung jawab tersebut merupakan sebuah komitmen untuk menjadi pribadi yang dapat dipercaya dalam perkataan, tindakan dan pekerjaan. Selanjutnya hal terpenting adalah mampu mempengaruhi orang lain agar tercapai tujuan organisasi OSIS, seperti pendapat Thoha (2010:9) yang mengatakan bahwa kepemimpinan adalah kegiatan untuk mempengaruhi perilaku orang lain, atau seni mempengaruhi perilaku manusia baik perorangan maupun kelompok.

Pengurus OSIS melaksanakan kegiatan dengan antusias berharap mampu mengembangkan kemampuan diri sehingga tidak hanya cakap dalam kegiatan akademik namun juga dalam kegiatan non akademik sesuai dengan tujuan kegiatan pembinaan kesiswaan yang teruat dalam Peraturan Menteri Pendidikan Nasional Nomor 39 Tahun 2008 Tentang Pembinaan Kesiswaan yang dilakukan melalui kegiatan OSIS. Pengurus OSIS dapat belajar tentang kepemimpinan dan organisasi sehingga mampu melatih kemampuan public speaking. Selain itu pengurus OSIS juga dapat berkontribusi secara aktif kepada sekolah dengan menyukseskan berbagai acara yang digelar.

Persoalan dalam pelaksanaan adalah bahwa dalam kepanitiaan yang menjadi ketua pelaksana hanya siswa yang sudah pernah melaksanakan sebelumnya dan tidak secara bergantian. Pengalaman dalam hal kepemimpinan menjadi kurang merata 
dan tidak semua pengurus OSIS merasakan pengalaman tersebut sehingga kurang memiliki inisiatif dan kreativitas serta tanggung jawab. Sikap kepemimpinan yang seharusnya dapat dilaksanakan oleh setiap orang dalam kepengurusan OSIS menjadi tidak merata, namun informan juga menjelaskan bahwa dalam suatu organisasi tidak mungkin semua orang dapat menjadi seorang pemimpin. Seperti misalnya dalam organisasi sekolah, yang menjadi pemimpin hanya kepala sekolah, bukan guru ataupun karyawan sekolah yang lain.

Pelaksanaan kegiatan OSIS di SMK Negeri 2 Blitar masih sering terkendala waktu karena di SMK lebih banyak melakukan praktik sesuai dengan jurusan masing-masing yang dilakukan dari pagi hingga sore hari guna memfasilitasi siswa sebagai bekal masuk ke dunia usaha dan industri setelah lulus nanti. Dengan prioritas untuk masuk dalam dunia kerja setelah lulus, maka kegiatan siswa SMK sebagian besar dilakukan untuk kegiatan praktik.

Secara terstruktur penumbuhan dan penguatan karakter kepemimpinan dilakukan dalam rangkaian kegiatan Latihan Dasar Kepemimpinan dan Manajemen Siswa. Kegiatan tersebut dilaksanakan pada awal masa bakti kepengurusan OSIS yang baru. Kegiatan pembekalan terhadap OSIS yang dilaksanakan tiga hari dua malam tersebut mengajarkan tentang bagaimana menjadi seorang pemimpin yang baik sekaligus materi tentang organisasi. Berdasarkan observasi yang telah dilakukan, selain kegiatan LDKMS, kegiatan yang dapat melatih sikap kepemimpinan OSIS adalah upacara bendera dan pelatihan barisberbaris. Kegiatan tersebut mampu melatih sikap kepemimpinan dan koordinasi yang baik dalam sebuah tim. Biasanya kegiatan upacara dilakukan setiap hari senin atau pada hari besar. Namun yang menjadi penanggung jawab utama dalam kegiatan tersebut adalah kelompok ekstrakurikuler Paskibraka.

Pelaksanaan kegiatan OSIS untuk menumbuhkan dan menguatkan karakter kepemimpinan telah dilaksanakan sesuai dengan desain kegiatan yang telah disebutkan sebelumnya, dimana pengurus OSIS melakukan kegiatan sesuai dengan program kerja guna mengembangkan kemampuan diri didampingi oleh pembina OSIS yang memberikan motivasi serta dorongan dan memberikan reward atas tindakan positif sekecil apapun itu. Kerjasama antar pengurus OSIS serta dukungan dari pembina OSIS dilakukan agar terwujud karakter kepemimpinan yang ideal.

\section{Dampak Pembinaan Kesiswaan untuk Penumbuhan dan Penguatan Karakter Kepemimpinan Melalui Kegiatan OSIS di SMK Negeri 2 Blitar}

Kegiatan pembinaan kesiswaan melalui OSIS dalam menumbuhkan dan menguatkan karakter kepemimpinan berdasarkan observasi dan wawancara yang telah dilakukan berdampak pengurus OSIS mampu memiliki sikap saling mengerti satu sama lain, mampu merencanakan kegiatan, mampu mengalokasikan anggaran, melakukan diskusi dan musyawarah, melatih public speaking dan bisa belajar berorganisasi.

Ketika yang dipelajari dalam OSIS cenderung tentang kepanitiaan, hal tersebut memiliki dampak negatif dan juga dampak positif. Dampak positifnya adalah dalam kepanitiaan dapat membentuk sikap kepemimpinan, dimana dalam kepanitiaan tersebut mengajarkan untuk saling mengerti satu sama lain, melaksanakan tugas dan kewajiban serta tanggung jawab yang telah diberikan. Sikap tanggung jawab tersebut merupakan sebuah komitmen untuk menjadi pribadi yang dapat dipercaya dalam perkataan, tindakan dan pekerjaan. 
Dampak negatif yang terjadi ketika melaksanakan suatu acara atau kegiatan adalah pengurus OSIS masih ada sifat egoisme yang mengakibatkan beberapa anak tidak berjalan beriringan sehingga menimbulkan kurangnya koordinasi. Kurang koordinasi tersebut terkadang menjadikan pengurus tidak mengetahui tentang tugas serta tanggung jawab yang harus dilaksanakan.

Berdasarkan observasi yang telah dilakukan, kegiatan OSIS juga berdampak pada kemampuan manajemen waktu yang baik. Sebagai seorang siswa yang memiliki kewajiban untuk belajar dan menyelesaikan tugas-tugas di sekolah, pengurus OSIS juga memiliki kewajiban lain di keseharian seperti rapat, briefing atau tugas-tugas yang lainnya. Untuk itu pengurus OSIS dituntut untuk mampu menyesuaikan waktu yang ada sehingga tidak ada tugas dan tanggung jawab yang terbengkalai. Meskipun terkadang masih harus meminta dispensasi agar diperkenankan untuk tidak mengikuti pelajaran, namun mereka tetap mampu berprestasi.

Mengacu pada parameter rangkaian kegiatan yang sudah dilaksanakan, tingkat partisipasi pengurus dalam kegiatan OSIS sudah mampu dilaksanakan dengan baik. Terbukti dari beragam agenda kegiatan yang telah berjalan dengan baik. Pengurus OSIS juga mampu berdiskusi serta melakukan musyawarah untuk menyelesaikan permasalahan yang terjadi. Musyawarah tersebut dilaksanakan pada saat akhir kegiatan untuk mengevaluasi kegiatan yang sudah dilaksanakan.

Dampak pembinaan kesiswaan untuk penumbuhan dan penguatan karakter kepemimpinan melalui kegiatan OSIS di SMK Negeri 2 Blitar secara konkret adalah terbentuknya karakter integritas. Nilai integritas yang ditampakkan adalah sikap mampu menjadi seseorang yang bertanggung jawab, disiplin, dan pantang menyerah dalam mencapai kinerja OSIS yang maksimal. Suatu organisasi tidak terlepas dari berbagai persoalan, halangan serta rintangan. Suatu organisasi tidak mungkin sempurn tanpa kecacatan sedikitpun. Oleh karena itu apabila terdapat suatu masalah, hal yang harus dilakukan adalah menekan agar tidak lebih besar dampak negatif daripada dampak positifnya.

\section{SIMPULAN}

Desain kegiatan untuk menumbuhkan karakter kepemimpinan diwujudkan dalam bentuk personal development dimulai dengan mengenali diri sendiri sehingga mampu mengarahkan sekaligus mengembangkan karakter diri utamanya dalam kepemimpinan mengharuskan siswa untuk bertanggung jawab terhadap diri sendiri terlebih dahulu sehingga memiliki integritas dengan begitu tanggung jawab yang lain juga ikut terlaksana dengan baik. Bertanggung jawab terhadap diri sendiri akan mendorong penumbuhan karakter secara alami pada siswa. Desain kegiatan untuk menguatkan karakter kepemimpinan yang telah tertanam dalam diri adalah melalui pelaksanaan kegiatan atau melalui kepanitiaan dimana dalam kepanitiaan tersebut mengajarkan untuk saling mengerti satu sama lain, melaksanakan tugas dan kewajiban serta tanggung jawab yang telah diberikan serta pemberian reward oleh pembina OSIS atas setiap capaian positif.

Pelaksanaan kegiatan OSIS untuk menumbuhkan dan menguatkan karakter kepemimpinan lebih sebagai agenda untuk membantu kegiatan sekolah seperti dies natalis atau orientasi siswa baru sehingga yang dipelajari adalah tentang kepanitiaan. Permasalahan yang timbul adalah pengalaman dalam hal kepemimpinan kurang merata dan tidak semua pengurus OSIS merasakan pengalaman tersebut karena yang menjadi ketua pelaksana hanya siswa yang sudah pernah bertugas sebelumnya sehingga yang lain kurang 
memiliki inisiatif dan kreativitas serta tanggung jawab.

Dampak kegiatan OSIS antara lain pengurus OSIS mampu memiliki sikap saling mengerti satu sama lain, bisa merencanakan kegiatan, mampu mengalokasikan anggaran, melakukan diskusi dan musyawarah, melatih public speaking dan bisa belajar berorganisasi. Ketika yang dipelajari dalam OSIS cenderung tentang kepanitiaan, hal tersebut memiliki dampak negatif dan juga dampak positif. Dampak positifnya adalah dalam kepanitiaan dapat membentuk sikap kepemimpinan karena mengajarkan untuk saling mengerti satu sama lain, melaksanakan tugas dan kewajiban serta tanggung jawab yang telah diberikan. Sikap tanggung jawab tersebut merupakan sebuah komitmen untuk menjadi pribadi yang dapat dipercaya dalam perkataan, tindakan dan pekerjaan.

\section{DAFTAR PUSTAKA}

Asmani, Jamal Ma'mur. 2009. Sekolah Life skills: Lulus Siap Kerja. Yogyakarta: Diva Press

Asril. Zainal. 2010. Micro Teaching. Jakarta: PT. Rajagrafindo Persada

Budiono, M.A. 2005. Kamus Lengkap Bahasa Indonesia. Surabaya: Karya Agung

Kadir. Abdul. 2001. Membangun Karakter Kepemimpinan. Yogyakarta: Andi Offset

Kartono, Kartini. 2005. Pemimpin dan Kepemimpinan. Jakarta: Rajawali Pers

Kunandar. 2007. Guru Profesional: Implementasi Kurikulum Tingkat satuan Pendidikan (KTSP) dan Sukses dalam Sertifikasi Guru. Jakarta: PT. Rajagrafindo Persada

Megawangi, Ratna. 2009. Pengembangan Program Pendidikan Karakter di Sekolah: Pengalaman Sekolah Karakter. Depok: Indonesia Heritage Foundation

Mulyasa. 2011. Menjadi Guru Profesional Menciptakan Pembelajaran Kreatif dan Menyenangkan. Bandung: PT. Remaja Rosdakarya Offset

Nurhasnawati.2005. Strategi Pembelajaran
Micro. Pekanbaru: Fakultas Tarbiyah dan Keguruan IAIN Sultan Syarif Kasim

Prayitno. 2009. Dasar Teori dan Praktis

Pendidikan. Jakarta: Grasindo

Peraturan Menteri Pendidikan Nasional

Nomor 39 Tahun 2008 Tentang

Pembinaan Kesiswaan

Peraturan Menteri Pendidikan dan Kebudayaan Nomor 20 Tahun 2018 Tentang Penguatan Pendidikan Karakter Pada Satuan Pendidikan Formal

Peraturan Perundang-Undangan Nomor 20 Tahun 2003 Tentang Sistem Pendidikan Peraturan Pemerintah Republik Indonesia Nomor 19 Tahun 2005 Tentang Standar Nasional Pendidikan

Pidekso, YS dan Harsiwi. 2001. Hubungan Kepemimpinan Transformasional dan karakteristik Personal Pemimpin. Jurnal Kinerja, vol 5, No 1 hal 70-81 Sugiyono. 2017. Metode Penelitian Pendidikan: Pendekatan Kuantitatif, Kualitatif, dan $R \& D$. Bandung: Alfabeta

Thoha, Miftah. 2010. Kepemimpinan dan Manajemen, Devisi Buku Perguruan Tinggi. Jakarta: PT. Rajagrafindo Persada

Usman. Moh. Uzer. 2013. Menjadi Guru Profesional. Bandung: Rosdakarya

Wahjosumidjo. 2010. Kepemimpinan Kepala Sekolah: Tinjauan Teoritik dan Permasalahannya. Jakarta: PT. Rajagrafindo Persada

Walgito. Bimo. 2003. Psikologi Sosial: Suatu Pengantar. Jakarta: Andi Winataputra, Udin S. 2005. Strategi Belajar Mengajar. Jakarta: Universitas Terbuka Zubaedi. 2012. Desain Pendidikan Karakter Konsepsi dan Aplikasinya dalam dunia Pendidikan. Jakarta: Kencana Prenada Media Group

Zuriah. Nurul. 2009. Metode Penelitian Sosial dan Pendidikan. Jakarta: Bumi Aksara 